\title{
Benito Fernández de Elena Garro: una mirada crítica sobre la historia mexicana
}

\section{Benito Fernández by Elena Garro: a critical look about the Mexican history}

\author{
Gerardo Bustamante Bermúdez \\ Universidad Autónoma de la Ciudad de México, México
}

\begin{abstract}
Resumen: En 1957, Elena Garro escribió la obra teatral Benito Fernández, texto en el que hace una revisión crítica a la historia nacional, el poder, la simulación y la búsqueda de la identidad personal en medio de la sociedad creada a partir de la posrevolución mexicana. La obra de la escritora es un contradiscurso a la oficialidad, a la mitificación de los hechos y héroes nacionales; lo que le interesa es resaltar el carácter racista y clasista de una nueva sociedad de dirigentes políticos en busca del bienestar personal y de grupo por encima del bien colectivo, para ello, opta porque en su obra los personajes se preocupen por comprar una cabeza, es decir, una ideología que les haga saber que existen.

Palabras clave: historia, poder, parodia, ideología, clase.
\end{abstract}

Abstract: In 1957, Elena Garro wrote the play Benito Fernández, a text in which she critically reviews Mexico's national history, issues of power, simulation and the quest for personal identity in the midst of a society emerged in the after effects of the Mexican Revolution. This work is a counter-discourse to Mexico's official narrative and the idealization of facts and national heroes. She is interested in the racist and classist aspects of the new dominating society, which is interested in their own personal welfare over those of the collective. To do so, she makes her characters concerned about buying a head, that is, an ideology to fundament their own existence.

Keywords: History, Power, Parody, Ideology, Class.

Recibido: 25 de noviembre de 2016 Aceptado: 20 de marzo de 2017 
Gri n 1991, Elena Delfina Garro Navarro (1916-1998) le confesó al periodista Luis Enrique Ramírez que el teatro es el género que más se le facilita, pero "como se me da tan fácil, me da flojera. El teatro se te ocurre en un momento. Y también, mira, escribes teatro y no lo montan. O lo montan muy mal, los estudiantes" (Ramírez, 1994: 236). En varias entrevistas y testimonios, la opinión de la autora fue similar (Pérez Vázquez, 2002; Landeros, 2007).

El signo semiótico de la representación teatral está por encima del texto escrito que por sí solo es literatura, es decir, un texto dramático existe en tanto que se materializa en un espacio escénico y con un entramado de hacedores escénicos que le dan voz, visión, dirección y sonido a una unidad artística. Efectivamente, el teatro de Elena Garro ha sido un tanto ignorado, al menos por las grandes compañías de teatro en México. Su puesta en escena ha sido posible más bien en el ámbito del teatro escolar y universitario. Además de lo anterior, hay que hacer notar que desde la ya legendaria edición que le hizo la Universidad Veracruzana en 1985 de Un hogar sólido y otras piezas dramáticas, que recopila textos no incluidos en la edición de 1959, el teatro de Garro era inconseguible. No será hasta el 2009 que el Fondo de Cultura Económica rescata en un tomo las 16 obras teatrales de esta insigne dramaturga, narradora, periodista y poeta.

Elena Garro nace como dramaturga el 19 de julio de 1957 , en el Teatro Moderno de la Ciudad de México, espacio en el que se llevó a cabo el IV Programa del famoso movimiento Poesía en Voz Alta, formado por artistas, dramaturgos, poetas, actores y escenógrafos como Juan Soriano, Octavio Paz, Juan José Arreola, Rita Macedo, Enrique Stopen, Leonora Carrington, Ana Ofelia Murguía, Juan José Gurrola, José Luis Ibáñez, Héctor Mendoza, entre otros. En ese cuarto programa, Elena Garro entra con el pie derecho al panorama de la dramaturgia mexicana con tres obras: 
Andarse por las ramas, Los pilares de doña Blanca y Un hogar sólido, bajo la dirección de Héctor Mendoza. La escritora Margarita Michelena refirió así el lanzamiento escénico de Garro:

Las tres farsas de Elena Garro son, por principio, la corroboración pública de un talento tan largo como injustificadamente ocultado por su dueña. Andarse por las ramas, Los pilares de doña Blanca y Un hogar sólido traducen la poesía a su forma más activa -alcaloide, diría yo- confiándola al vehículo que, tradicionalmente, la ha hecho más directa y comunicable [...]

Con estas páginas de las que fluye la frescura metafórica más rica y más viva, Elena Garro prueba -contra toda esa literatura de señoras a las que, como dice Quevedo, se las conoce más por los circunloquios que por los mońos, y la de esos señores, digo yo, a los que se conoce más por las pelucas que por los circunloquiosque la inocencia, que la facultad de maravillarse son el mágico manantial de donde brota, temblando en su gracia original, infalsificable, la poesía. Y que la poesía es, a su vez, la única forma posible de recobrar la verdadera sabiduría, esto es, la inocencia (1957: 59). ${ }^{1}$

Las piezas dramáticas de Garro oscilan entre el lenguaje simbólico, poético, mágico y onírico. Garro había sido conocedora

${ }^{1}$ La crítica teatral de la ciudad de México puso el acento en la entronización de Elena Garro como una gran dramaturga. Pareciera que con estas piezas dramáticas había nacido una autora que cambiaba el rumbo, al menos desde la escritura y la poesía, del teatro nacional. Otras críticas celebratorias de la obra de Garro en el IV Programa de Poesía en Voz Alta son: Armando de Maria y Campos, "El hogar sólido. Éxito de Elena Garro en Poesía en Voz Alta: demostró su talento", Novedades, México, 21 de julio de 1957, sección 2, pp. 11-12; "Luis G. Basurto, "Teatro. Un hogar sólido, Excélsior, 27 de julio de 1957, sección B, p. 4; Alejandro Moreno Ling, "Teatro. IV Programa de Poesía en Voz Alta", La Nación, México, 28 de julio de 1957, p. 31; Juan García Ponce, "Poesía en Voz Alta. El cuarto programa", Revista de la Universidad de México, México, agosto de 1957, pp. 29-30, 32. 
durante su niñez del teatro clásico español, pero, sin lugar a dudas, su conocimiento y posible contagio con el arte y el teatro vanguardista europeo pudo darse porque vivió de 1946 a 1952 en París. La Europa de la posguerra de ese entonces se convirtió en el centro de las revoluciones artísticas, y la escritora mexicana tuvo contacto con esos textos teatrales cuando asistía a los montajes. El teatro realista había quedado rebasado por el horror de la guerra; hablar de lógica y verosimilitud resultaba, hasta cierto punto, insulso; de ahí que el poder y remoción artística de vanguardias como el cubismo, dadaísmo, futurismo y surrealismo -formas literarias en las que se adscribe la protesta artística y política de esos aciagos tiempos- tuviera que apostar por la reelaboración de una realidad en términos de la abolición de la lógica.

El teatro de Garro sólo es mimético en el sentido en que algunas de sus historias quedan ubicadas en escenarios mexicanos de provincia, pero el ingrediente extrańo, onírico y mágico se agrega cuando recurre al tópico del tiempo circular, ese que se repite a manera de espiral, cuando la suerte inexorable revela que ciertos temas como la violencia hacia las mujeres, la violación y la muerte son, al menos desde el contexto mexicano, una forma de resurgimiento de actos debido a la misoginia cultural histórica.

$\mathrm{Al}$ regreso de Elena Garro a México, sus inquietudes literarias estaban un tanto influenciadas por ese ambiente vertiginoso y vanguardista de Europa, por eso su teatro es único, sobre todo porque la dimensión poética y onírica no había sido trabajada de manera sostenida por ningún otro dramaturgo. Agréguese que Garro se interesó por llevar al terreno del teatro la cosmovisión indígena, el tema de la violencia de género, la soledad femenina, la relación del mexicano con la muerte y las desigualdades de clase.

A decir de Alejandro Ortiz Bullé Goyri, la dramaturgia de Garro está más allá de comparaciones o inserciones asociadas con las vanguardias europeas. El crítico aduce que "No es pues un teatro 
mágico el de Elena Garro, ni surrealista, ni mucho menos teatro del absurdo a la mexicana. Considero que los rasgos no realistas de su teatro son recursos estilísticos, el vaso que contiene un discurso de reflexión existencial, que es esto último su verdadera esencia" (1994: 31). El argumento del crítico encaja perfectamente en el discurso ideológico que Elena Garro plantea al revisar la historia mexicana, particularmente la posterior a la Revolución Mexicana, reflexiones que dejó en sendos artículos periodísticos de tema social, escritos durante las décadas de los cuarenta a sesenta del siglo XX. Además de lo anterior, es importante notar que en Elena Garro hay una visión cotidiana sobre acontecimientos extraños y mágicos desde que jugaba con sus hermanas durante la infancia al juego de los encantados. De ahí que el tiempo detenido, la voluntad y la conversión de personas en objetos, aparezcan dentro de su obra como un recurso estético desde la mirada de los lectores y la crítica, pero posible desde su visión y experiencia. ${ }^{2}$ Confiesa Garro en entrevista: "En Los recuerdos del porvenir Isabel termina convertida en piedra, pero eso es real, porque en Guerrero hay montón de gente que se convierte en piedra. Que fulanita andaba en malos pasos y en una de esas quedó hecha piedra, cuentan, y yo lo creo. Pero eso no es magia, es más que magia” (Ramírez, 235).

Elena Garro siempre estuvo interesada por la historia nacional mexicana, incluso apartada del método de estudio de la historiografía publicó en 1968 varios textos sobre protagonistas de la Revolución Mexicana, en donde revisa la vida y acciones de personajes como Francisco I. Madero, Ricardo Flores Magón, así como a otros revolucionarios de la llamada "decena trágica" para, finalmente, hacer un balance sobre el periodo 1910-1946, que va del Porfiriato a la llamada época de la modernidad nacional. Estos

${ }^{2}$ Además de la confesión en varias entrevistas, la autora evoca su infancia y juventud, así como la relación con el tiempo en el documental La cuarta casa. Un retrato de Elena Garro (2001), de José Antonio Cordero. 
reportajes biográficos fueron publicados a manera de libro en 1997 en Seix Barral bajo el título Revolucionarios mexicanos.

Las ideas políticas y sociales de la autora quedan emparentadas con su teatro, particularmente en la pieza que aquí analizaremos. Garro no es ajena a la historia nacional, por el contrario, la estudia y cuestiona y desde esos márgenes habla, sobre todo cuando desde el espacio de la literatura incorpora la vida y cosmovisión campesina e indígena, pues de acuerdo con Margo Echenberg,

La mayor parte de la obra de la narradora y dramaturga poblana Elena Garro, incluye una crítica socio-política como parte esencial de su temática. Se trata de una visión crítica que problematiza la desigualdad de su sociedad, pues en sus escritos el patriarcado estrangula al "otro", entendido no solamente en relación al género sexual, sino también como relevante clase social, el grupo étnico, la cultura y la marginación. De ahí que los pobres, los indígenas, las mujeres, los niños y los animales figuran más entre sus personajes literarios (2011: 135).

Los conceptos de "otredad" y marginación se vinculan estrechamente con el de clase social, en atención crítica a la llamada modernidad nacional. Dentro de la obra dramática de Elena Garro Benito Fernández constituye un ejemplo claro de cómo estos conceptos se relativizan en la medida en que la caída o el ascenso social y económico posibilitan o interrumpen una forma de ser dentro de la sociedad mexicana. En esta obra, Garro no pone como protagonistas a los indios, sino que cuestiona el ascenso social a manera de contradiscurso, pues si la historia oficial habla sobre la Revolución como un proceso histórico en donde el indio aparece como el héroe muerto, entonces es necesario que las voces dramáticas representen las condiciones en las que se dio ese ascenso de clase y la muerte de un sector social. La pregunta central sería entonces, ¿para qué las luchas armadas? 
Benito Fernández es una pieza fársica ${ }^{3}$ breve que pasa revista a la historia nacional, principalmente a ciertos pasajes de la Independencia, la Revolución Mexicana y el nacimiento de una nueva clase dirigente que defiende sus intereses de ascenso social. Esta obra es una alusión al escritor Fernando Benítez, considerado por la autora de Los recuerdos del porvenir como un magnate arrogante del periodismo cultural en México, según me contó Helena Paz Garro:

Mi mamá no se llevaba bien con Fernando Benítez porque era muy pedante y quería que todos los escritores del momento se rindieran a sus pies [...] Viejo con cara de vinagrillo. Se quejaba con mi papá por la escritura de la obra que hizo mi mamá. Esa obra la escribió como en una semana. Benítez se puso verde de coraje porque en varios sentidos mi mamá supo reflejar todos sus complejos, incluidos los sexuales. Nunca la quiso [a Elena Garro] ni ella a él. ${ }^{4}$

Por su parte, Lucía Melgar, en entrevista con Garro afirma lo expuesto por la hija de la escritora respecto a la inspiración de manera burlesca hacia la figura de Benítez, director del famoso suplemento México en la Cultura. Garro afirma: "hice el 'Benito Fernández'... y Octavio Paz se partía de risa -porque la hice en una hora, ¡rápido!-, y fíjate tú que Octavio se rió mucho [pero luego]

${ }^{3}$ Patrice Pavis considera que la farsa es un subgénero dramático que se asocia con la idea de una comicidad grotesca y bufonesca, "de una risa gorda y de un estilo poco refinado: meros calificativos condescendientes y que establecen de entrada, y a menudo de modo abusivo, que la farsa se opone al espíritu, que es cómplice del cuerpo, de la realidad y de lo cotidiano" (1999: 205). La farsa es un tipo de obra que establece la tradición de un no sentido; generalmente se ha emparentado con el desarrollo de una historia de tema escatológico. En sentido estricto, la obra de Garro sólo cumple la noción de lo bufonesco y la verosimilitud atrofiada.

${ }^{4}$ Entrevista personal con Helena Paz Garro, concedida en el Asilo Villa Laurel, Cuernavaca, Morelos, agosto de 2009. 
me hizo prometer que nunca la iba a publicar. Le dije: "Bueno, no, ¡nunca!... y tardé años. Sí, tardé muchísimo” (Melgar: 2002: 259).5

La severa crítica social que hace Garro en su obra quizás sólo pueda tener comparativo con El gesticulador de Rodolfo Usigli, que pone al desnudo el tema de la burocracia nacional y las políticas acomodaticias que se erigen en la tradición posrevolucionaria; la obra fue prohibida en 1938 por el gobierno de Lázaro Cárdenas y se estrenó hasta 1947.

Dentro de la producción dramática de Elena Garro, Benito Fernández ha sido una de las menos atendidas no sólo a nivel del estudio del texto, sino de la puesta en escena. El nivel simbólico de las cabezas como objetos/sujetos hace posible que el cuidado escénico de la obra se mantenga dentro del terreno de la farsa y no de la comedia; es decir, la presentación de las cabezas debe plantearse como un asunto posible, por lo que la estética de las mismas no debe simular la de simples cabezas de muñecos o accesorios de juguete porque el tema de la historia nacional y la identidad del mexicano resultan un tópico central y serio en la obra de la autora poblana.

A través de la metáfora de la venta de cabezas -ideologías, vidas e historias- la autora permite reflexionar sobre el tiempo histórico y el presente de la escritura, que incluye su particular visión crítica sobre ese México que nace con la Revolución. No se trata solamente de una obra escrita en 1957, sino de un texto que hace ecos sobre la mitificación o la leyenda hecha por parte del Estado en oposición a la realidad nacional llena de simulaciones y desigualdades sociales; en ese sentido, la dramaturga se convierte en una conciencia reaccionaria. Desde esta perspectiva, la autora estaría

${ }^{5}$ Las declaraciones de Garro quedan sólo en el nivel de la confesión, pues Benito Fernández no tiene ninguna alusión directa que haga que el lector asocie al protagonista con el escritor Fernando Benítez, autor de obras como Los indios de México (1989). 
postulando la misma idea que el filósofo Jorge Portilla, quien en Fenomenología del relajo (1966) refiere que parte de las grandezas y miserias del mexicano consisten en erigir aplausos sobre un personaje y no propiamente por la ideología como posibilidad de progreso y bien común:

Nuestra historia es la de unas cuantas individualidades señeras que emergen de tiempo en tiempo sobre el pantano quieto de las sordas pugnas políticas. Es la historia de la acción de los caudillos y de sus seguidores personales. Los mexicanos no creemos tanto en el liberalismo como en Juárez; no tanto en el orden y el progreso como en Porfirio Díaz; no tanto en la reforma agraria y en el movimiento obrero cuanto en Zapata y en Cárdenas; y el liberalismo, el orden y el progreso, la democracia, la reforma agraria y obrera no existen si no existe Juárez, Díaz, Madero, Zapata o Cárdenas. El pecado político verdaderamente grave no es tanto el cambiar de ideología o de programa cuanto la fidelidad personal del caudillo (1984: 136).

Con esta paradoja entre sujeto e ideología podemos entender la propuesta artística de la obra de Garro, ya que los personajes al comprar cabezas en un mercado de antiguallas se enfrentan a la cuasi divinidad de caudillos a los que hay que imitar o a los que hay que adherirse para ingresar o conservar el stablisment socioeconómico. La gente "descabezada" se explica desde la metáfora de la pérdida o la búsqueda de una ideología, no importa cuál sea, pues lo único que se pretende es visibilizarse dentro de esos nuevos tiempos mexicanos.

La trama de Benito Fernández es la siguiente: hasta un puesto de cabezas en el mercado de la Lagunilla, en la ciudad de México, llegan Luisita y su sobrino Benito, viejos representantes de una aristocracia porfirista arruinada con la llegada de la Revolución. Llega también un joven de clase media que no tiene el dinero suficiente para comprarse una cabeza a su medida. Después hace su 
aparición un gobernador, quien va en busca de una cabeza para su esposa. También llegará Vicky, una joven rebelde e hija de un diputado, representante de los discursos oficialistas del progreso, la modernización y el orden. Cada uno de ellos pretende conseguir una cabeza para mejorar su vida y alcanzar un estatus, según los nuevos tiempos. Al final, los personajes protagonistas no lo logran, sino que por el contrario, se provoca una tragedia.

Lo que Garro está planteando es la noción de identidad simuladora del mexicano de la posrevolución, pues casi todos los personajes de su obra pretenden conseguir la cabeza de un icono histórico, de ahí que la nostalgia por el pasado porfirista les acentúe a los personajes de Luisita y Benito la angustia por existir en medio de un contexto actual que juzgan de primitivo. No pertenecer a un círculo poderoso supone no existir, porque en México se existe sólo en función del poder individual de un personaje que se vuelve colectivo cuando se defienden los intereses de clase. De ahí que el letrero que cierra la obra se traduzca como un signo visual que debe pensarse en términos de la reflexión sobre las subjetividades nacionales, la existencia o el anonimato. Reza el letrero: "Cómprese una cabeza y sabrá quién es” (283). Con esta frase se plantea la adopción de una identidad que permita el ser en medio de un contexto nacional complejo y carente de ideologías. Quien no es está fuera del poder y del beneficio que otorga la política nacional recién instaurada, por eso es necesario comprarse una cabeza en el contexto de los nuevos tiempos.

En términos generales, Benito Fernández plantea el tema de la identidad nacional atrofiada y el sentimiento de los venidos a menos o a más a partir de la Revolución. La autora hace una crítica de la historia oficial, a los discursos sobre la subalternidad, el poder y la alienación de los sujetos empeñados en la apariencia. A través de Benito Fernández, personaje principal que carece de cabeza, la autora presenta a un México aparentemente moderno que tiene 
vínculos con un pasado inmediato, pero también lejano, pues el tema de la segregación social y el exterminio indígena tienen sus orígenes en la conquista.

Según Ute Seydel, en México sigue prevaleciendo una memoria hegemónica "que concuerda con la elaboración de los hechos históricos por la historia oficial y se divulgan en los manuales escolares de historia” (2007: 172). Para esta autora, quien ha estudiado ampliamente las correspondencias entre historia y ficción en la obra de Garro, los hechos literarios se presentan como un contradiscurso, pues con frecuencia cuando se habla o se recrean personajes históricos se recurre a:

parodiar ciertas imágenes y crear cierta ambigüedad a través del registro de lo fantástico, del realismo mágico, de la ironía, de la alegoría, la metáfora, la parodia, etc. Todos estos recursos propician la creación de un relato plurivocal en el que los juicios se expresan de un modo refractado, exigiendo al lector que colabore en la evaluación de las actuaciones y de las decisiones que tomaron los personajes históricos (173).

Así pues, el contradiscurso de Elena Garro permite parodiar la ideología del mexicano y la idea de nación, progreso y estatus. Según la construcción dramática, el público participa dialécticamente en un tiempo presente -el de la representación-; reflexiona sobre la historia nacional y el pasado, así como de los vínculos de dependencia y subordinación que guarda la política mexicana, siempre sujeta a los designios de un poder que se institucionaliza después de la Revolución Mexicana. La obra de Garro se plantea como un intertexto que funciona a partir de la historia patria de corte nacionalista y como un intertexto literario que hace eco en otros artículos periodísticos y ensayos de tema político e histórico escritos por la autora; incluso, también, en novelas eminentemen- 
te políticas como Los recuerdos del porvenir (1963) y Matarazo no llamó (1991).

Para hablar sobre esta pieza de Elena Garro conviene retomar algunas ideas sobre la epistemología de la escritura de la historia que desarrolla Paul Ricoeur en Tiempo y narración, pues ahí el autor señala que hay una intersección entre la función poética de la historia y la hermenéutica de la conciencia histórica. Para Ricoeur existen dos componentes que desde el relato ficcional pueden desprenderse: 1) la epopeya y 2) la historiografía. Ricoeur retoma al estructuralista Émile Benveniste para referir que en el relato hay un "tiempo crónico" que pertenece al tiempo diacrónico del calendario y que se traduce como una condición necesaria de las sociedades para ubicar acontecimientos de interés general. A partir de esta funcionalidad cronológica del tiempo es posible recorrer a éste desde dos direcciones "desde el pasado hacia el presente y desde el presente hacia el pasado" (2003: 787). Lo anterior permite reelaborar una epistemología del pretérito con la finalidad de signar los acontecimientos y valorarlos desde el presente de la enunciación. Aplicando el modelo de lectura sobre el tiempo que propone Ricoeur, podemos decir que Garro plantea desde mediados de la década de los cincuenta del siglo XX una lectura sobre la historia colectiva nacional, particularmente sobre los episodios que permitieron un cambio de dirección política, social y económica, con resultados parciales: la conquista, la colonia, la Independencia, la Revolución, la posrevolución y la modernidad. Lo interesante del discurso ideológico de Benito Fernández en relación con el tiempo es la deconstrucción de esquemas oficiales a través del uso de la ironía y la parodia ${ }^{6}$ como recursos que plantean la continuación o co-

${ }^{6}$ Linda Hutcheon define la ironía con una antífrasis de oposición "entre lo que se dice y lo que se quiere hacer entender, incluso como una marca de contraste". Esta figura opera en el nivel pragmático. En tanto que por parodia, la autora dice que se trata de una superposición de textos e intenciones con el fin de crear 
pia simple de personajes acomodaticios. En este sentido, desde el presente de la representación o la lectura, el público escucha a esos personajes del pasado, actualiza los códigos en el tiempo diacrónico de la historia mexicana, ya que como bien afirma Ricoeur: "Para tener un presente es necesario [...] que alguien hable; el presente es entonces seńalado por la coincidencia entre un acontecimiento y el discurso que lo enuncia; para alcanzar el tiempo vivido a partir del tiempo crónico, es preciso, pues, pasar a través del tiempo lingüístico referido, al discurso" (790). Por lo anterior, considero que en la obra de Garro existe también una intersección entre el tiempo histórico crítico -a través de la ironía- y el tiempo histórico de la representación, pues el lector/espectador puede dialogar con los discursos del pasado - los institucionales y los críticos que la autora propone a través de sus personajes- y desde ahí preguntarse qué dice la obra Benito Fernández sobre el pasado-presente.

La obra de Elena Garro contribuye a reinscribir el pasado histórico; a través del discurso ideológico y opuesto de los personajes, los espectadores asistimos a una hermenéutica de la temporalidad del calendario patrio, con sus correspondientes historias colectivas y personales; pues se trata de una obra en la que el personaje de Luisita llega con su sobrino hasta el mercado con el fin de poder comprar una cabeza de alcurnia que les recuerde mejores tiempos y les permita vivir en la opulencia del pasado. No obstante, la época de los cincuenta, caracterizada en México por el afán modernizador de Miguel Alemán, ha abierto la posibilidad para que exista la clase media, representada por el Cliente I, un joven con aspiraciones de progreso que no tiene el dinero suficiente para comprar una cabeza útil para el nuevo tiempo histórico, incluso su timidez al momento de acercarse al puesto de cabezas de Julián, el depen-

una desviación de sentido con una intención de burla y que con frecuencia opera desde la intención de lo carnavalesco. Para mayor información sobre estas figuras, véase el artículo "Ironía, sátira, parodia”, consignado en la bibliografía. 
diente que resguarda ese pasado nacional, lo hace que pregunte sobre la autenticidad de las cabezas, ya que le preocupa la falsificación. Garro pone a discusión también el tema de la autenticidad, pues las imitaciones impiden llegar a tener el status.

\section{CLIENTE I: ¿'Son muy caras?}

JULIÁN (elocuente): Una cabeza nueva nunca es cara, joven. Nomás piense, distintos pensamientos, distinta cara y diferente suerte. ¿Le parece caro?

CLIENTE I: Bueno, usted dirá. ¿A cómo? ¿Cuánto más o menos?...

JULIÁN: Depende, joven. Hay de todos precios y para todos los gustos y todas las necesidades, según el cliente es la cabeza y el precio.

CLIENTE I: ¿Y me garantiza que son buenas?...

JULIÁN (Con aire de suficiencia): ¿Buenas? ¡Ay qué caray! Mis cabezas son las mejores de toda la Lagunilla. Y para decirlo bien y pronto, de todo México, joven. Usted busque y ya verá cómo regresa. No impongo mi mercancía, pero conozco mi negocio.

CLIENTE I: No, yo sólo quería saber si no eran copias... (Garro, 2009: 262).

Por otra parte, la obra se encarga de personificar al Cliente II, un gobernador a la usanza priísta que anda en busca de una cabeza para su esposa. Este personaje resulta particularmente importante porque representa la opulencia triunfalista de la época posrevolucionaria; es el nuevo político con poder e influencias para actuar incluso desde la impunidad. Para la construcción de este sujeto, la dramaturga opta por conservar la oralidad arcaica del personaje como alusión a la figura del político ignorante que desconoce los principios básicos de la teoría política. Aquí un ejemplo: "Estamos de acuerdo, ¿verdad? La política es también la discreción, aunque no lo crean los que andan fuera de ella" (269). El discurso de este hombre alberga todavía palabras como "camarada", "jefe", "traba- 
jo" o "Revolución"; todos ellos vocablos de la demagogia de un presente que nos permite juzgar bajo el calendario patrio que los triunfalistas se convirtieron en los nuevos ricos de la Nación, por eso, cuando aparece en escena Luisita, comenta con la frustración de sentirse despojada: "Es un pobre individuo, de esos venidos a más, de los trepadores, y como todos los de su clase desparraman millones y procacidades" (269). Y efectivamente, la presentación del Cliente II queda planteada no sólo en su lenguaje ranchero, sino en la didascalia previa a su aparición, que lo presenta como un sujeto kitsch: "Viene apresurado. Viste un traje de seda azul brillante. Usa reloj de oro en la muñeca, pañuelo de seda en el bolsillo de la chaqueta, corbata a rayas azules y amarillas y zapatos de cuero de cocodrilo. Lleva el pelo brillante y bigote recortado" (268). El Cliente II sabe que su condición política le permitirá trabajar por un proyecto personal que le facilite el ascenso en las filas de los poderosos. Para lograrlo, ha aprendido, a su manera el parlamento teatral, los discursos revolucionarios, mismos que le permiten hablar sobre los nuevos tiempos. Una vez que ha comprado la cabeza de la señorita Ulloa, misma que portará su esposa Chona, el político se niega en pagar el precio completo:

CLIENTE II: (saca unos billetes de su billetera medio vacia y se los tiende a Julián) Aquí tienes cincuenta pesos, a mí no me vengas con que las cabezas contrarrevolucionarias son tan caras. ¿`No sabes cuánto luchamos por derrotarlas? Y tú, compañero, me vienes a hacer su elogio. $\mathrm{Y}$ entonces, ¿qué? ¿La Revolución no sirve? ¿Y qué me dices del millón de muertos por el Sufragio Efectivo y de tanto sacrificio? No, mano, no. Andas desencaminado, admirando a la reacción y haciéndome su elogio. Yo soy tu amigo, no diré nada, porque no quiero perjudicarte y que te cierren el puesto, pero modérate, mano (272). 
A lo largo de la obra da la impresión de que Garro pretende poner en escena a tres tipos de personajes, cuya condición histórica en los ańos cincuenta los hace estar en contacto/conflicto: Luisita y Benito, que son los aristócratas arruinados; Cliente I y Julián, pertenecientes a la clase media, y el Cliente II y Victoria, los nuevos ricos que están de lado de la política, representan la corrupción y la frivolidad. El Cliente II piensa en un futuro histórico que lo posicione en una suerte de performance político en el sentido escénico de la representación del poder respecto a la mirada que las clases subalternas tienen sobre el progreso y la ayuda social. Su afán de protagonismo sabe que lo llevará a ser recordado por su figura y no por su ideología. El personaje de Julián le ofrece la cabeza de la señorita Ulloa, una mujer del Porfiriato, de clase y gustos refinados, pues de esta manera, el gobernador podrá presumir el ascenso, es decir, la falta de clase -tan necesaria en la política mediática mexicana de la modernidad, puede comprarse-. Dice Julián:

Piense, jefe, en el quince de septiembre en el Palacio Nacional. ¡Bien peinada, con sus buenas plumas de avestruz y sus buenos aretes de diamantes! ¿Qué más pide? Véala en un reparto de la Nochebuena, con su sombrero de ala ancha, bien pintada, acabadita de salir del salón de belleza, cómo va a brillar entre las cabezas pobres. ¡Una reina! Es una cabeza de lujo, una cabeza que debe subir muy alto. Ahora piénsela junto a la Campana de Dolores, cuando le llegue su turno, que a lo mejor es el próximo sexenio (270).

Entre un antes y un ahora, las cabezas de alcurnia suponen la compra o imitación de un estilo de vida de aquellos oportunistas que se colocaron en las instituciones de poder y desde ahí reproducen un discurso sobre la igualdad, la lucha y el progreso, aunque en la práctica el estilo de vida frívolo revele su ineficacia e incluso su antipatriotismo, sobre todo porque lo que se defiende es un proyecto personal por encima de las desigualdades sociales. 
Dentro de la compra de un pasado, Julián ofrece la cabeza de la señorita Ulloa, perteneciente a la sociedad aristócrata porfirista. El dinero puede comprar la clase, la memoria y los pensamientos de otro, por eso, el vendedor de cabezas, con un lenguaje poético y onírico, dice:

La señorita Ulloa soñaba mucho, con estanques, con lagos, con violines, con veleros y hasta con cisnes. El que la compre se lleva a su casa la música de muchas arpas, los gestos hipnóticos de muchos muertos, y los caminos que llevan a los pasajes secretos de las noches muertas hace muchos años. (Julián acaricia los cabellos de la cabeza) En estos bucles se pasean pájaros disecados, músicas difuntas, fiestas paralizadas, carretelas negras, lacayos enlutados y caballos con enormes penachos de garzas nocturnas (263).

Dentro del tipo de personajes acomodaticios, Victoria ocupa un lugar importante, pues su juventud rebelde y su posición social privilegiada la hacen figurar como un sujeto no sólo inconsciente de la historia nacional reciente, sino que desconoce incluso la propia historia oficial; sólo le interesa vivir su juventud y establecer un bar en el segundo piso de su casa, al que adornará con cabezas de negros y llamará Safari, en franca alusión exótica sobre la construcción cultural de la negritud africana y su estado de subordinación frente al poder del hombre blanco y europeo que compra en el mercado cabezas (ideologías, mano de obra, exotismo) de culturas consideradas históricamente inferiores desde la visión colonialista. Dice Victoria a Julián:

VICTORIA: ¡Don Julián, envuélvame todas las cabezas de negros que le queden! Tengo prisa, esta noche voy al Jacarandas con una runfla de vaciladores. ¡Son vaciados! Anoche me llevaron serenata con guitarras hechas de armadillos. ¿Se da cuenta? Hubiera visto usted a mi papá, ya quería sacar su placa de diputado y su pistola. ¡Es tan intransigente! Se quedó en los tiempos de Tom Mix. Sólo 
le gustan los caballos, las pistolas, los discursos y los informes presidenciales. ¡Pero no es justo, a mí me aburren! (279).

La obra de Elena Garro, además del discurso directo en voz de los personajes, plantea al menos dos elementos simbólicos: 1) las cabezas humanas de diferentes personajes, ya sea anónimos, históricos o de posición social encumbrada son lo que permite o impide el reconocimiento; 2) el elemento simbólico de la ceniza hacia el final de la obra es una metáfora del tiempo convulso del tiempo dramático y del tiempo histórico. En el primer caso se trata de una alusión crítica a la falta de identidad y a la simulación del mexicano, en tanto que en el caso de la ceniza, de acuerdo con el Diccionario de símbolos de Cirlot, la descomposición de la materia se identifica con lo alquímico, "con la muerte y la disolución de los cuerpos. Simboliza así el instinto de muerte o cualquier situación en la que el retorno a lo inorgánico surge como amenaza” (2003: 130). En tanto descomposición, la ceniza que cae sobre el escenario al final de la obra no sólo anticipa el fin de los personajes en tanto que individuos perecederos, sino que contempla la ruptura de esa conciencia histórica del calendario del que habla Ricoeur. La ceniza es el último elemento de la existencia humana. En esta obra también se puede entender que la ceniza es una metáfora de la confusión y lo ininteligible de la historia porque el elemento ceniza no puede leerse, es sólo confusión, nebulosidad.

Por su parte, el símbolo de las cabezas, que en la obra funciona como un motivo que justifica el tema y la trama, se puede entender como la alegoría de un país descabezado, con una identidad nacional atrofiada, cambiante, pues la cabeza en las diferentes culturas se asocia a la producción de discursos y a la vida espiritual; por su forma, es también la imagen del mundo, "una asimilación de la cabeza y la esfera" (Cirlot, 2003: 119), es por ello que al adquirir una cabeza ajena en el mercado de la Lagunilla, Benito Fernández sufre una metamorfosis mental. La cabeza-discurso-identidad que 
ha comprado es fácilmente perceptible en la obra; se trata del fascista italiano Benito Mussolini, pues a pregunta expresa de Luisita, Julián le responde: "La verdad, señorita, que yo tenía escondida esa cabeza de titiritero italiano, o al menos eso me dijo el hombre que me la vendió, que por cierto era forastero. Usted fue la que la escogió. Yo no me atrevía a vendérsela... Ya la vendí una vez y hubo muchos muertos... y por eso la tenía escondida. Con lo desconocido no hay que jugar..." (289). Julián es un hombre sin edad -en el reparto sólo se le atribuye su oficio de vendedor de cabezas-; su presencia escénica tiene un halo de omnipotencia, pues el tiempo no pasa sobre él. Julián es el depositario y testigo de un tiempo histórico nacional e internacional, es también un visionario, por eso le dice a Luisita:

JULIÁN: Modestamente, señora, he visto ¡todo! Y cuando digo todo, es todo. Desde aquí, desde este puesto, humilde, mis ojos han visto lo que muy pocos ojos han mirado. Por ejemplo, ahora la veo a usted entrando a la vecindad en la que vive, por República de El Salvador, y veo también la casa en la Colonia Juárez a la que usted y su sobrino quieren mudarse, sólo que para eso se necesita una cabeza (274).

La obra Benito Fernández también abre la posibilidad de pensar los temas de las razas y clases sociales en México, particularmente desde la visión sobre lo indígena, pues si en el puesto de cabezas de Julián se pagan quinientos pesos por una cabeza aristócrata o trescientos pesos por la de un soldado raso, la de un indio vale diez pesos. ¿Dónde queda el discurso histórico de los campesinos e indios como protagonistas de la Revolución? La obra de Garro es contundente al respecto: 
Julián les muestra una cabeza de indio.

BENITO: ¡Diez pesos por una cabeza de indio! ¡Qué escándalo! Cualquier fraccionador las consigue gratis y ni siquiera las vende.

LUISITA: Esas cabezas se tiran, no se cotizan en el mercado.

JULIÁN: Es verdad. No se venden. Como la mercancía ésta abunda, ha bajado mucho su precio (275).

En la obra de Garro cada personaje representa una ideología del México que, al menos en el discurso estatal de los ańos cincuenta, pretende ser moderno, lo que supone el progreso, por un lado, pero también la ańoranza por un pasado mejor que se ha perdido con la Revolución Mexicana.

La compra de cabezas dentro de la obra de Garro presupone el cuestionamiento crítico de las individualidades por encima de las ideologías. A través de la compra de una cabeza el tiempo se vuelve cíclico, a la manera de una espiral que no se sabe dónde empiezan ni terminan los movimientos ondulares. Comprarse una cabeza supone repetir discursos e ideologías, pero también identidades.

Sin duda, los planteamientos de Elena Garro lesionan considerablemente las ideologías conservadoras, seudoprogresistas y modernizantes de los años cincuenta del siglo pasado; aquellas que registraron que las luchas armadas pretéritas posibilitaron el nacimiento del progreso. El pensamiento político de la autora de Los recuerdos del porvenir, más allá de su básica formación historiográfica, al menos desde la academia, tiene mucho sentido para México porque la obra escrita en 1957 sigue siendo vigente, ya que la historia nacional ha sido una lucha de intereses de clase, simulación y performance, en el sentido escénico del término. Benito Fernández es por tanto una pieza fársica que deconstruye los discursos colonialistas, independentistas y revolucionarios de la historia nacional. Con esta pieza dramática, la autora expone el amplio mosaico 
de la composición social del mexicano moderno, su lucha de clases y su sentido aspiracionista.

\section{Bibliografía}

Cirlot, Eduardo, 2003, Diccionario de simbolos, Barcelona, Siruela.

Cordero, José Antonio, 2001, La cuarta casa. Un retrato de Elena Garro, (documental), México, Instituto Mexicano de Cinematografía/Centro de Capacitación Cinematográfica.

Echenberg, Margo, 2011, "Muros falsos: Espacios domésticos y narrativos en "El árbol" de Elena Garro", en Sáenz, Adriana y Cándida Elizabeth Vivero (comps.), Reflexiones en torno a la escritura femenina, México, Universidad Michoacana de San Nicolás de Hidalgo/Universidad de Guadalajara, pp. 135-155.

Garro, Elena, 1997, Revolucionarios mexicanos, México, Seix Barral.

, 2009, Obras reunidas II. Teatro, Patricia Rosas Lopátegui (intro.), México, FCE.

Houtcheon, Linda, 1992, "Ironía, sátira, parodia. Una aproximación pragmática a la ironía”, De la ironía a la grotesco (en algunos textos literarios hispanoamericanos), México, UAM-I.

Landeros, Carlos, 2007, Yo, Elena Garro, México, Lumen.

Michelena, Margarita, 1957, "Poesía en Voz Alta: creación y revolución”, Hoy, México, 17 de agosto, pp. 58-59.

Ortiz, Bullé-Goyri, Alejandro, 1994, "A propósito del teatro de Elena Garro", en Elena Garro. Reflexiones en torno a su obra, Domingo Adame (intro.), CONACULTA/INBA.

Pavis, Patrice, 1998, Diccionario del teatro. Dramaturgia, estética, semiología, Anne Ubersfeld (prefacio), Barcelona, Paidós. 
Pérez Vázquez, Reynol, 2002, “¿Cuándo tendré un hogar sólido. Una conversación con Elena Garro”, en Lucía Melgar y Gabriela Mora (comps.), Elena Garro. Lectura múltiple de una personalidad compleja, México, BUAP, pp. 231-236.

Portilla, Jorge, 1984, Fenomenología del relajo y otros ensayos, México, FCE.

Ricoeur, Paul, 2003, Tiempo y narración III. El tiempo narrado, México, Siglo XXI Editores.

Seydel, Ute, 2007, Narrar historia(s). La ficcionalización de temas históricos por las escritoras mexicanas Elena Garro, Rosa Beltrán y Carmen Boullosa, España, Iberoamericana/Vervuert. 